\title{
MSI2/HOXA9 Fusion Protein
}

National Cancer Institute

\section{Source}

National Cancer Institute. MSI2/HOXA9 Fusion Protein. NCI Thesaurus. Code C99828.

A fusion protein encoded by the MSI2/HOXA9 fusion gene. This protein is comprised of the 2 RNA recognition motifs in the RNA-binding protein Musashi homolog 2 fused to the homeodomain of the homeobox protein Hox-A9. 